\title{
CORRIGENDUM
}

Genes \& Development 30: 2158-2172 (2016)

\section{Corrigendum: Mutations in genes encoding condensins cause microcephaly through decatenation failure at mitosis}

Carol-Anne Martin, Jennie E. Murray, Paula Carroll, Andrea Leitch, Karen J. MacKenzie, Mihail Halachev, Ahmed E. Fetit, Charlotte Keith, Louise S. Bicknell, Adeline Fluteau, Philippe Gautier, Emma A. Hall, Shelagh Joss, Gabriela Soares, João Silva, Michael B. Bober, Angela Duker, Carol A. Wise, Alan J. Quigley, Shubha R. Phadke, The Deciphering Developmental Disorders Study, Andrew J. Wood, Paola Vagnarelli, and Andrew P. Jackson

In the above-mentioned article, the authors neglected to acknowledge the source of the Caph $2^{115 \mathrm{~N}}$ mutant mouse line. These mice were kindly provided by Aude Fahrer at the Australian National University and are identical to the Caph2 $2^{\text {nes }}$ mutant line reported by Gosling et al. 2007. The authors apologize for this omission.

doi: $10.1101 / \operatorname{gad} .300871 .117$ 


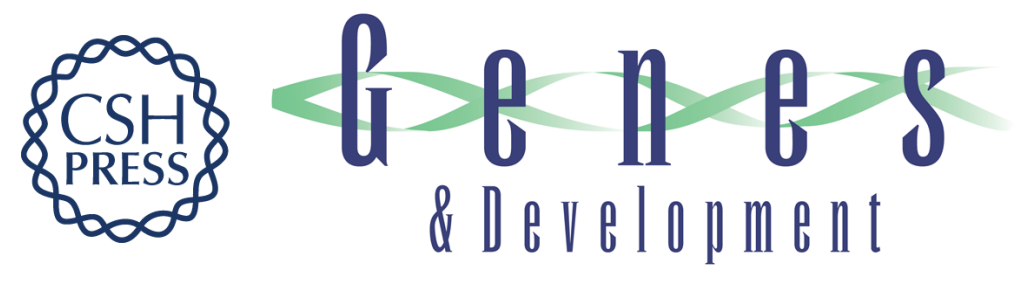

\section{Corrigendum: Mutations in genes encoding condensins cause microcephaly through decatenation failure at mitosis}

Carol-Anne Martin, Jennie E. Murray, Paula Carroll, et al.

Genes Dev. 2017, 31:

Access the most recent version at doi:10.1101/gad.300871.117
Related Content Mutations in genes encoding condensin complex proteins cause microcephaly through decatenation failure at mitosis
Carol-Anne Martin, Jennie E. Murray, Paula Carroll, et al.
Genes Dev. October , 2016 30: 2158-2172
License
Email Alerting Receive free email alerts when new articles cite this article - sign up in the box at the top
Service right corner of the article or click here.

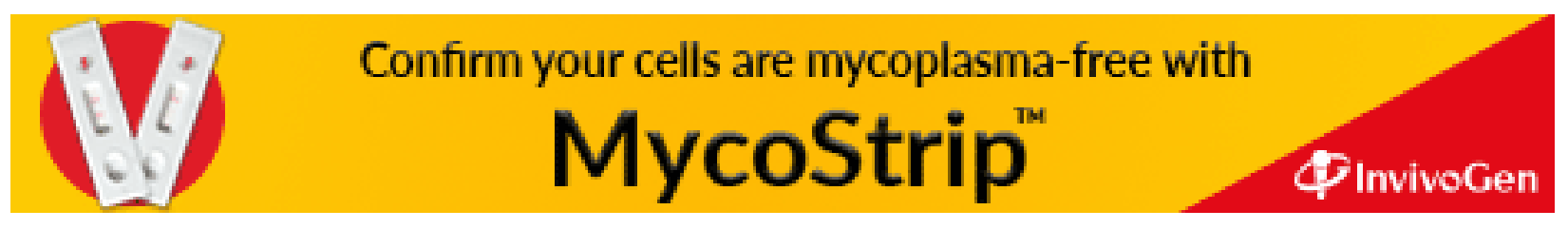

